variation of the obliquity and the first-order term in the planetary precession, respectively. Fricke has continued to investigate all observational evidence for an excess secular change of the obliquity and has found that the individual values $\Delta \varepsilon$ derived from observations after 1900 do not deviate significantly from zero and do not show a significant secular decrease".

Par ailleurs, des recherches sont activement poursuivies à l'Astronomisches Rechen-Institut en vue d'améliorer le catalogue FK4 (voir, plus loin, le rapport de cet Institut). D'autre part, la résolution suivante, proposée par le colloque No. 20 sur l'astronomie méridienne, devra être examinée par la commission 4.

"It is recommended that an improvement of the FK4 and its extension to a fainter magnitude limit, resulting in a new fundamental catalogue, the FK5, be carried out at the Astronomisches Rechen-Institut, Heidelberg; that observatories throughout the world contribute to this project by providing basic observations, on punched cards if possible; and that all information pertinent to the formation of the FK5 be transmitted to the Astronomisches Rechen-Institut with the observations".

\title{
BIBLIOGRAPHIE
}

1. Fricke, W. 1971, Astr. and Astrophys, 13, 298.

2. Laubscher, R. 1972, Astr. and Astrophys., $20,407$.

\section{RECHERCHES SUR LES ÉPHÉMÉRIDES DES PLANÈTES}

Le rôle joué par les tables des positions des planètes publiées par les Éphémérides Nationales ou Internationales est considérable. Elles jouent le rôle essentiel dans la comparaison des observations avec la théorie et la longue durée des théories assure la cohérence nécessaire pour réduire les observations à une référence commune.

On peut cependant penser qu'on aurait une cohérence encore plus grande s'il était possible de construire des théories de l'ensemble du système solaire en intégrant numériquement le mouvement du système et en déterminant les conditions initiales et le système de masses planétaires. Par ailleurs, cette méthode permet d'utiliser les observations récentes et par conséquent introduire dans les éphémérides toute la précision des nouvelles techniques d'observation.

Au Jet Propulsion Laboratory, D. A. O'Handley nous communique les précisions suivantes:

"In 1970, the first simultaneous numerical integration of the motion of the planets with the solar system data processing system (SSDPS) was made by W. G. Melbourne and D. A. O'Handley. This ephemeris (Development Ephemeris 69) utilized optical observations from the U.S. Naval Observatory, radar observations from Arecibo (Puerto Rico), the Massachusetts Institute of Technology and the Jet Propulsion Laboratory, and Mariner 5 radio tracking data. This ephemeris was issued for general use by anyone requesting a copy through Computer Software Management and Information Center (COSMIC), University of Georgia, Athens, Georgia 30601. This ephemeris now replaces Development Ephemeris 19 (DE 19).

An ephemeris improved over DE 69 was completed by D. A. O'Handley and J. H. Lieske for the Mariner 9 orbital mission about Mars. This ephemeris included an expanded radar data set which contained Mars radar observations extending through the 1971 opposition (1).

Further work on the improved planetary ephemerides continues under J. H. Lieske. C. F. Peters is initiating an effort to improve the ephemerides of the satellites of Jupiter and Saturn. This later effort will be made in conjunction with several U.S. and foreign organizations. The simultaneous solution for the masses of the principal planets obtained at JPL (2) is also the result of an improvement of DE 69 using various combinations of observational data."

Un effort analogue a été effectué au Naval Weapons Laboratory (Dahlgren) où Oesterwinter et Cohen (3) ont amélioré simultanément les orbites des planètes et de la Lune. L'intégration numérique a été exécutée par la méthode de Cowell et la comparaison avec 40000 observations optiques depuis 1913 a été faite par la méthode des moindres carrés. Le modèle comprend les corrections relativistes et de nombreux paramètres relatifs au potentiel de la Terre et de la Lune. 
Au Massachusetts Institute of Technology, on a rassemblé plus de 150000 observations optiques du Soleil, de la Lune et des planètes, pour la période 1750 à 1968 et un certain nombre de solutions du mouvement des planètes ont été obtenues par intégration numérique du système de masses planétaires (4).

Par ailleurs, l'U.S. Naval Observatory a procédé à l'analyse de la précision des éphémérides existantes, notamment des grosses planètes (5) tandis que des études étaient faites à l'Institut d'Astronomie Théorique de Léningrad sur le calcul des Éphémérides (6) et (7).

\section{BIBLIOGRAPHIE}

1. O'Handley, D. A. and Lieske, J. H. $\quad$ 1971, Bull. Amer. Astron. Soc., 3, 467.

2. Lieske, J. H., Melbourne, W. G., O'Handley, D. A., Holdridge, D. B., Johnson, D. E. and Sinclair, W. S. 1971, Celestial Mechanics, 4, 233.

3. Oesterwinter, C. and Cohen, C. J. 1972, Celestial Mechanics, 5, 317.

4. Ash, M. E., Shapiro, I. I. and Smith, W. B. 1971, Science, 174, 551.

5. Duncombe, R. L., Klepczynski, W. J. and Seidelmann, P. K. 1972, Astronautics and Aeronautics, 10, No. 8 .

6. Izvekov, V. A. 1972 , Bull. Inst. Theor. Astr., 13, No. 4.

7. Gromova, O. M. and Malkova, A. G. $\quad$ 1972, Bull. Inst. Theor. Astr., 13, No. 7.

\section{ÉPHÉMÉRIDES DE LA LUNE ET TE2}

Le lancement de nombreuses sondes lunaires habitées ou non, et le fait que l'on mesure maintenant de façon systématique la distance Terre-Lune par laser ont rendu plus nécessaire que jamais la construction d'éphémérides précises de la Lune. Nous tirons du rapport de J. D. Mulholland la description des efforts faits dans ce domaine:

"During the triennum, considerable progress has been made towards the construction of a very high-precision numerical ephemeris of the Moon. A preliminary step in this effort was the use of a combination of literal and numerical integration techniques to produce a lunar ephemeris free of the gravitational defect inherent in the Brown lunar theory, due to a series truncation in the planetary terms (1). This ephemeris, which was developed by the writer while at the Jet Propulsion Laboratory, was intended to serve as the primary prediction ephemeris for the Apollo Lunar Laser ranging Experiment, a role that it is still fulfilling. It is based on the same observational material as is the Brown Lunar theory.

Another ephemeris (JPL designation LE 17) was obtained through a completely gravitational numerical integration of the Moon's orbit fitted to U.S. Naval Observatory transit circle observations over the interval $1950-1968$ by J. D. Mulholland. It differs from the first ephemeris described above on the scale of two to three hundred meters. In comparison with observations, both transit circle and lunar ranges, it proved not to be better or worse".

Les observations systématiques de distance laser Terre-Lune ont d'ores et déjà permis d'améliorer les éphémérides de la Lune. W. G. Melbourne écrit à ce sujet:

"The ability to analyse lunar laser range data has been developed by P. Bender, J. D. Mulholland and J. G. Williams. Current laser ranging observations from McDonald observatory are considered to be accurate to better than $15 \mathrm{~cm}$. Solutions can be made for the lunar elements, the observatory and reflector coordinates and physical libration parameters. These solutions show significant corrections to the lunar eccentricity, mean anomaly and longitude of perigee. New numerical integrations with the improved elements" (University of Texas Integrated Ephemeris No. 1 and JPL ephemeris LE 18) "confirm the significant decrease in the range residuals. However, the residuals are still considerably larger than the inherent accuracy of observations. The existing physical libration model appears to be the main limitation to the present analysis of laser data. The libration model is being improved at JPL".

Les efforts parallèles faits pour améliorer la théorie analytique de la Lune ou pour rassembler des 